\title{
Does parity and labor influence anxiety levels of pregnant women?
}

\author{
Zeliha Çiğdem Demirel Güler ${ }^{1}$ (D) , Aşkın Evren Güler ${ }^{1}$ (D) , Mehmet Ferdi Kıncı ${ }^{2}$, Erhan Aktürk ${ }^{3}$ \\ ${ }^{\prime}$ Obstetrics and Gynecology Clinic, Koru Ankara Hospital, Ankara, Turkey \\ ${ }^{2}$ Department of Obstetrics and Gynecology, Muğla Sıtkı Koçman University Training and Research Hospital, Mŭ̆la, Turkey \\ ${ }^{3}$ Department of Obstetrics and Gynecology, Istanbul Okmeydanı Training and Research Hospital, Istanbul, Turkey
}

\begin{abstract}
Objective: Our aim for this study is to examine state anxiety levels in the prenatal period in the presence of different forms of parity and birth types.

Methods: A retrospective study was conducted to collect the results of pregnant woman which has different parities and type of deliveries in our tertiary center between June and December 2013. 186 cases were divided into 3 groups. Group $1(\mathrm{n}=60)$ consists of primiparous pregnant women who are expected to give birth spontaneously, Group $2(n=64)$ consists of multiparous pregnant women whose will be their second birth with spontaneous vaginal delivery and Group 3 $(\mathrm{n}=62)$ consists of elective cesarean section and second-trimester pregnant women. State and Trait Anxiety Inventory (STAI) analysis was made during antenatal pregnancy follow-up at 37 weeks of gestation.

Results: When patients were divided into groups of normal, mild anxiety, moderate anxiety and severe anxiety, 124 (66.6\%) of the patients were found to be anxious. In the group of anxious patients, it was found that $95.9 \%$ of the patients had mild anxiety. No patient is severely anxious. Especially in Group 1, the patient ratio was higher than the other groups with $85 \%$. In Group 3, it was shown that the majority of the patients $(50 \%)$ evaluated as normal compared to other groups.

Conclusion: The anxiety levels of pregnant women are generally mild and women who have already experienced birth and did not experience pain have reduced anxiety levels.
\end{abstract}

Keywords: Anxiety, elective cesarean section, STAI.

\section{Introduction}

During pregnancy, many physiological, psychological and anatomical changes are seen in the female body. These changes nurture the development of fetus and

\section{Özet: Parite ve doğum, gebelerde kaygı seviyelerini etkiliyor mu?}

Amaç: Bu çalışmadaki amacımız, farklı parite ve doğum türlerinin varlığında prenatal dönemde durumluk kaygı seviyelerini incelemektir.

Yöntem: Haziran - Aralık 2013 tarihleri arasında üçüncü basamak merkezimizde farklı paritelere ve doğum türlerine sahip gebelerin sonuçlarını toplamak amacıyla retrospektif bir çalışma gerçekleştirdik. Yüz seksen altı olgu 3 gruba ayrıldı. Grup $1(n=60)$ spontan doğum yapması beklenen primipar gebelerden, Grup $2(n=64)$ spontan vajinal doğum ile ikinci doğumlarını yapacak multipar gebelerden ve Grup 3 ( $n=62)$ elektif sezaryen ve ikinci trimester gebelerden oluşmaktaydı. Gebeliğin 37. haftasındaki antenatal gebelik takibi esnasında Durumluk ve Sürekli Kaygı Envanteri (State and Trait Anxiety Inventory, STAI) analizi yapıldı.

Bulgular: Hastalar normal, hafif kayg1, orta seviye kayg1 ve şiddetli kaygı gruplarına ayrıldı ve 124 (\%66.6) hastada kaygı saptandı. Kaygı hastalarının olduğu grupta hastaların \%95.9'unda hafif kayg1 bulundu. Hiçbir hasta şiddetli kaygıya sahip değildi. Özellikle Grup 1'in hasta oranı, $\% 85$ oran ile diğer gruplardan daha fazlayd. Grup 3 'teki hastaların çoğu (\% 50), diğer gruplara kıyasla normal olarak değerlendirildi.

Sonuç: Gebelerin kaygı seviyeleri genellikle hafiftir ve daha önce doğum yapmış ve ağrı yaşamamış gebeler düşük kaygı seviyelerine sahiptir.

Anahtar sözcükler: Kaygı, elektif sezaryen, Durumluk ve Sürekli Kaygi Envanteri.

prepare the mother for labor. ${ }^{[1]}$ Also childbirth, aside from the pregnancy process, is an important experience. Sometimes it can be one of the serious traumas. ${ }^{[2}$ Pregnancy, birth process and types of birth can cause

Correspondence: Mehmet Ferdı Kıncı, MD. Department of Obstetrics and Gynecology, Muğla Sıtkı Koçman University Training and Research Hospital, Muğla, Turkey. e-mail: drferdikinci@gmail.com / Received: April 15, 2019; Accepted: May 24, 2019

Please cite this article as: Demirel Güler ZÇ, Güler AE, Kıncı MF, Aktürk E. Does parity and labor influence anxiety levels of pregnant women? Perinatal Journal 2019;27(1):43-48. doi:10.2399/prn.19.0271007 
anxiety. The severity of this anxiety varies. For women, not knowing how the birth process and the type of birth are going to be and the fear of pain related to birth, are the reasons that can cause anxiety. ${ }^{[3,4]}$ Also, the fear of harm or death of the baby or the mother, fear of extreme pain, distrust of the medical personnel, the thought of losing control can be the common causes of anxiety. ${ }^{[5-8]}$

Excessive anxiety and stress before birth can cause prolonged labor and as a result, it causes operative births and the fetus to be adversely affected. ${ }^{[9]}$ Furthermore, anxiety is very important in terms of increasing the severity of birth pain. In the literature, anxiety is classified as two different types; continuous and state anxiety. In our study, state anxiety levels of women were measured. State anxiety; is a type of anxiety that occurs when a dangerous, undesirable situation is encountered. ${ }^{[10]}$

It is important that the nurse, midwife and obstetricians, who are in charge before and during birth, should be aware of the level of anxiety of the expectant and should plan their approaches to manage childbirth. This is why further studies on the state anxiety before birth are needed. Our aim for this study is to examine state anxiety levels in the prenatal period in the presence of different forms of parity and birth types.

\section{Methods}

Our study was designed on 186 patients who were done pregnancy follow-up at Private Koru Ankara Hospital, Obstetrics and Gynecology Clinic. Ethical approval for the study was obtained from the Ethics Committee of Koru Ankara Hospital (Ethics Committee protocol code: 13/11/2018-16). The study was conducted in accordance with the Helsinki declaration. 186 cases were divided into 3 groups. Group $1(n=60)$ consists of primiparous pregnant women who are expected to give birth spontaneously, Group 2 ( $n=64)$ consists of multiparous pregnant women whose will be their second birth with spontaneous vaginal delivery and Group $3(n=62)$ consists of elective cesarean section and secondtrimester pregnant women.

\section{Data collection}

As a primary measurement tool, "patient polyclinic history information screen" which all sociodemographic data was recorded, was used. As a secondary measure- ment tool STAI (State-Trait Anxiety Inventory) FORM TX-1 was used. These forms were filled during antenatal pregnancy follow-up at 37 weeks of gestation.

\section{Data collection tools}

\section{STAI-1 (State-Trait Anxiety Inventory)}

In order to measure the level of preoperative anxiety, many survey studies were conducted. These studies need to be renewed in parallel with the differences between countries and regions and sociocultural changes in society. The most commonly used test for the measurement of anxiety in medicine is the State-Trait Anxiety Inventory (STAI) scale. ${ }^{[10]}$ With the inventory, which was started to be developed by Spielberger and Gorsuch in 1964, it was aimed to measure continuous and state anxiety levels in normal and non-normal individuals. ${ }^{[1]}$ In preparation of inventory articles, Cattell and Scheier's Anxiety Scale, Taylor's Manifest Anxiety Scale and Welsh's Anxiety Scale articles were used. ${ }^{[12]}$ The validity in Turkish population was demonstrated by Le Compte and Oner. ${ }^{[13]}$

In order to perform STAI-1 test in our study, the participants were asked to mark the best expression on the scale that is numbered from 1 to 4 , with the options "none", "a little", "a lot" and "completely". In the scales, there are two kinds of expressions. We can also call them direct and reverse expressions. Direct expressions express negative feelings and reverse expressions express positive feelings. While this second round is scored, 1 weight value changes to 4 , and 4 weight value changes to 1 . In direct expressions, 4 valued answers show that the anxiety is higher. In reverse expressions, 1 valued answers show high anxiety, 4 valued answers show low anxiety. ${ }^{[9]}$

In the state anxiety scale, there are ten reverse expressions. Those are articles 1, 2, 5, 8, 10, 11, 15, 16, 19 and 20 . In these articles, 4 points are given to 1,3 points to 2 , 2 points to 3 and 1 point to $4 .{ }^{[0]}$ In state anxiety scale, there are ten direct expressions. Those are articles 3, 4, 6, $7,9,12,13,14,17$, and 18 . In these articles, 1 point is given to 1,2 points to 2,3 points to 3 and 4 points to 4 . In order to calculate state anxiety, the results obtained from direct and reverse expressions are collected. 40 and below 40 results are evaluated as normal, 41-60 mild anxiety, $61-80$ moderate anxiety, 80 and above are evaluated as severe anxiety.

In our study, values 40 and below are evaluated as normal, values 41 and above evaluated as anxious and are categorized to be mild, moderate, severe anxiety. 


\section{Implementation of the research}

The 1st study group consisted of 71 pregnant women who were monitored, 37 weeks of gestation and who were expected to have primiparous and normal birth in our polyclinic. The survey study was conducted to the 2nd study group consisted of 68 multiparous women whose spontaneous vaginal delivery was delivered spontaneously. The survey study was conducted to the 3rd study group 69 multiparous women whose first delivery was performed by cesarean section and the current birth was planned by cesarean delivery. 15 pregnant women from Group 1 and 4 from Group 2 were excluded because of interventions during childbirth. Due to an emergency cesarean section was performed before the planned date, 7 pregnant women from Group 3 were excluded from the study. Pregnant women who have a history of psychiatric disease or diagnosis; pregnant women with maternal metabolic diseases such as hypertension, gestational diabetes mellitus (GDM); pregnant women with fetal antenatal problems such as growth retardation, polyhydramnios, and oligohydramnios were not included in the study.

\section{Statistical analysis}

All statistical analyses were performed using the SPSS ver. 25.0 (SPSS Inc., Chicago, IL, USA). The data were evaluated by the Kolmogorov-Smirnov test for normal distribution. No data group was found to be suitable for normal distribution. Because there were more than two independent groups and they were not suitable for nor- mal distribution, the difference between the groups was investigated by Kruskal-Wallis $\mathrm{H}$ test. In case of significant difference, pairwise comparisons after Bonferroni correction for multiple tests were obtained. Comparisons of percentages between literature and the current study were performed by "chi-square test for goodness of fit". Descriptive statistics were used to calculate the frequency, central tendency (mean, median \& mode) and dispersion (range, variance, $\mathrm{SD}$, maximum \& minimum) for each variable when appropriate. A p-value $<0.05$ has been considered statistically significant.

\section{Results}

No statistically significant difference found between the three groups in terms of mother's working status, data collection weeks, birth weeks and newborn weight (Table 1). When age is evaluated, also there is no statistically difference between three groups (Group 1: 28.38 \pm 1.74 , Group 2: 27.96 \pm 1.16 , Group 3: 28.21 \pm 2.01 ; $\mathrm{p}=0.454$ ) (Table 1). When BMI is evaluated, also there is no statistically difference between three groups (Group 1: 21.72 \pm 3.16 , Group 2: 22.18 \pm 3.01 , Group 3: 21.88 \pm 2.92 ; $\mathrm{p}=0.436)$ (Table 1).

In the Kruskal-Wallis test, there was statistically significant difference between at least two groups $(\mathrm{p}<0.001)$. To find out which groups were different, we followed pairwise comparisons. As a result, $1-2(\mathrm{p}=0.001)$ and $1-3$ $(\mathrm{p}=0.014)$ groups were found to be different (Table 2). In

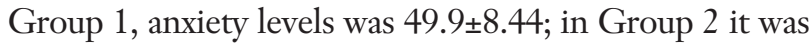

Table 1. Baseline characteristics of patients.

\begin{tabular}{|c|c|c|c|c|}
\hline & $\begin{array}{c}\text { Group } 1 \\
\text { Primiparous } \\
(n=60)\end{array}$ & $\begin{array}{c}\text { Group } 2 \\
\text { Multiparous } \\
(n=64)\end{array}$ & $\begin{array}{c}\text { Group } 3 \\
\text { Elective cesarean section } \\
(n=62)\end{array}$ & p-value* \\
\hline Age (years) & $28.38 \pm 1.74$ & $27.96 \pm 1.16$ & $28.21 \pm 2.01$ & 0.454 \\
\hline Gravidity (n) & $1(1-2)$ & $2(2-4)$ & $2(2-4)$ & 0.01 \\
\hline Parity (n) & $0(0-0)$ & $1(1-1)$ & $1(1-1)$ & 0.01 \\
\hline BMI $\left(\mathrm{kg} / \mathrm{m}^{2}\right)$ & $21.72 \pm 3.16$ & $22.18 \pm 3.01$ & $21.88 \pm 2.92$ & 0.436 \\
\hline \multicolumn{5}{|l|}{ Working during pregnancy } \\
\hline Working n (\%) & $39(65)$ & $40(62.5)$ & $39(62.9)$ & 0.310 \\
\hline Not working n (\%) & $21(35)$ & $24(37.5)$ & $23(37.1)$ & 0.082 \\
\hline Data collection week (weeks) & $37.12 \pm 0.28$ & $37.32 \pm 0.81$ & $37.28 \pm 0.71$ & 0.814 \\
\hline Birth week (weeks) & $39.2 \pm 0.24$ & $39.14 \pm 0.31$ & $38.66 \pm 0.45$ & 0.097 \\
\hline Newborn weight (g) & $3450 \pm 172.12$ & $3400 \pm 180.23$ & $3440 \pm 167.48$ & 0.111 \\
\hline
\end{tabular}


Table 2. Evaluation of anxiety levels according to groups.

\begin{tabular}{|c|c|c|c|c|}
\hline & $\begin{array}{c}\text { Group } 1 \\
\text { Primiparous } \\
(n=60) \\
\text { Mean } \pm \text { SD }\end{array}$ & $\begin{array}{c}\text { Group } 2 \\
\text { Multiparous } \\
(n=64) \\
\text { Mean } \pm \text { SD }\end{array}$ & $\begin{array}{c}\text { Group } 3 \\
\text { Elective caesarean } \\
(\mathrm{n}=62) \\
\text { Mean } \pm \text { SD }\end{array}$ & p-value \\
\hline Anxiety levels & $49.9 \pm 8.44$ & $43.43 \pm 5.73$ & $45.58 \pm 5.25$ & $<0.001^{*}$ \\
\hline
\end{tabular}

*Kruskal-Wallis test: To find out which groups were different we followed pairwise comparisons. As a result, 1-2 ( $p=0.001)$ and $1-3$ ( $p=0.014)$ groups were found to be different.

$43.43 \pm 5.73$; in Group 3 it was $45.58 \pm 5.25$ (Table 2) (significance values have been adjusted by the Bonferroni correction for multiple tests).

When patients were divided into groups of normal, mild anxiety, moderate anxiety and severe anxiety, 124 $(66.6 \%)$ of the patients were found to be anxious (Table $3)$. In the group of anxious patients, it was found that 119 $(95.9 \%)$ of the patients had mild anxiety, $5(2.68 \%)$ of the patients moderate anxiety and no patient is severely anxious (Table 3). In Group 1, the patient ratio was higher than the other groups with $51(85 \%)$, but most of the anxious patients was mild (90.2\%) (Table 3).

All patients with moderate anxiety (5 patients) were in Group 1 (Table 3). In Group 3, it was shown that the half of the patients (50\%) evaluated as Normal, other half of the patients (\%50) was mild anxiety (Table 3).

\section{Discussion}

Fear is defined as the usual reaction to a perceived or existing danger. This reaction motivates people to warn themselves in the face of danger and to show convenient behavior towards it. ${ }^{[1,15]}$ Obstetricians and gynecologists observe the fears and anxiety of the patients during their examinations and interventional procedures (hysterosalpingography, amniocentesis, cordocentesis, etc.) in their daily practices. ${ }^{[16-18]}$
Childbirth is a process in which the results are unpredictable and there are uncertainties. Many women face the fear of childbirth. This fear, like other physiological changes, prepares the pregnant woman for the postpartum period. ${ }^{[19]}$ Childbirth appearing in many different levels and reasons, may adversely affect the course of labor and prepare maternal and neonatal complications, if in severe stage. ${ }^{[15]}$

Mild or moderate fear of childbirth is very common in many women. Studies show that some women face severe fear of childbirth. In the studies of Kjærgaard et al., it was shown that $10 \%^{[2]}$ of pregnant women face severe fear of childbirth and in the studies of Spice et al., $9.1 \%$ of pregnant women face severe fear of childbirth. ${ }^{[2]}$ In our study, it was found that $2.68 \%$ of the patients face moderate anxiety and none of the patients face severe anxiety (chi-square test for goodness of fit; $\mathrm{p}=\mathrm{NA}$ ).

Age is one of the factors known to be effective in the development of anxiety related to birth. ${ }^{[2,23]}$ In our study, the average age of women in three groups was $28.38 \pm 1.74,27.96 \pm 1.16$ and $28.21 \pm 2.01$, respectively. In the evaluation of women facing anxiety related to childbirth, $97.31 \%$ of the patients were found to have normal or mild anxiety. In some studies, it was reported that the levels of anxiety were higher in pregnant

Table 3. Anxiety levels of groups.

\begin{tabular}{lcccc} 
& $\begin{array}{c}\text { Group 1 } \\
\text { Primiparous } \\
\mathbf{( n = 6 0 )}\end{array}$ & $\begin{array}{c}\text { Group 2 } \\
\text { Multiparous } \\
(\mathbf{n}=64)\end{array}$ & $\begin{array}{c}\text { Group 3 } \\
\text { Enxiective cesarean section } \\
(\mathbf{n}=62)\end{array}$ & $\begin{array}{c}\text { Total } \\
(\mathbf{n}=\mathbf{1 8 6})\end{array}$ \\
Normal & $9(15 \%)$ & $22(34.37 \%)$ & $31(50 \%)$ & $62(33.33 \%)$ \\
Mild & $46(76.66 \%)$ & $42(65.62 \%)$ & $31(50 \%)$ & $119(63.97 \%)$ \\
Moderate & $5(8.33 \%)$ & $0(0 \%)$ & $0(0 \%)$ & $5(2.68 \%)$ \\
High & $0(0 \%)$ & $0(0 \%)$ & $0(0 \%)$ & $0(0 \%)$ \\
\hline
\end{tabular}


women with advanced maternal age ${ }^{[22]}$ and adolescent pregnant women. ${ }^{[23]}$ It is thought that because pregnant women in our study are 25-30 years of age and that the pregnancy is planned and the family may be more ready for the pregnancy, they experience less anxiety.

In the study of Arslan et al., $26.5 \%$ of the pregnant women were found to work. ${ }^{[2]}$ According to the Turkey Demographic and Health Survey (TNSA) 2013 data, the rate of working women was defined as $31 \% .{ }^{[25]}$ The rate of working women in our study was $63.44 \%$ (chi-square test for goodness of fit; $\mathrm{p}=0.362$ ). We think that the reason why we have higher number of working pregnant women compared to the data of Arslan et al. and TNSA 2013 is because our hospital is preferred by patients with higher income. Therefore, it is difficult to evaluate the population of our patients according to the average of our country. This is a limitation of our study.

In the study of Arslan et al., a significant relationship between the number of pregnancies and anxiety and depression scores of the pregnant women participating in the study was found; as the total number of pregnancies increased, anxiety and depression scores also increased $(\mathrm{p}=0.004) .{ }^{[24]}$ On the contrary, in our study, it was found that the anxiety in the primiparous pregnant women was more common than the multiparous group and the planned cesarean section $(\mathrm{p}=<0.001)$. The average patient with normal anxiety score was the most common in Group 3 (multiparous patients with elective cesarean section) $(50 \%)$. We think that this case has occurred because the patients have experienced birth psychology before and have not experienced pain. These data is supported by Alehagen et al. with a limited number of patients and their work during the followup of nurses. ${ }^{[2]}$

In the literature, it is reported that the care and education service received in the antenatal period reduces the fear of childbirth. ${ }^{[27]}$ In recent years, the rate of cesarean delivery is increasing all over the world, especially in our country. ${ }^{[28,29]}$ In the study of Burns et al., it was determined that maternal cesarean delivery was due to doctor referral. ${ }^{[30]}$ In the hospital, where our study takes place, "Pregnancy Education Classes" are created by doctors, many social activities are carried out with pregnant women. We think this situation reduces the fear of birth of patients.

\section{Conclusion}

The aim of this study was to determine the levels of anxiety during the birth of pregnant women with different parity history. According to the research results, we think that the anxiety levels of pregnant women are generally mild and women who have already experienced birth and did not experience pain have reduced anxiety levels. Also in the hospital where the study takes place, antenatal care is performed regularly and pregnant women are given regular training by doctors and auxiliary health personnel. We think this situation reduces birth anxiety. Our study was performed on a homogeneous patient population. The comparison of our results with more heterogeneous populations and studies on more patients will be more valuable in terms of interpretation of results.

Conflicts of Interest: No conflicts declared.

\section{References}

1. Soma-Pillay P, Nelson-Piercy C, Tolppanen H, Mebazaa A. Physiological changes in pregnancy. Cardiovasc J Afr 2016; 27:89-94.

2. Emerson WR. Birth trauma: the psychological effects of obstetrical interventions. Journal of Prenatal and Perinatal Psychology and Health 1998;13:11-44.

3. Alipour Z, Lamyian M, Hajizadeh E, Vafaei MA. The association between antenatal anxiety and fear of childbirth in nulliparous women: a prospective study. Iran J Nurs Midwifery Res 2011;16:169-73.

4. Hall WA, Hauck YL, Carty EM, Hutton EK, Fenwick J, Stoll K. Childbirth fear, anxiety, fatigue, and sleep deprivation in pregnant women. J Obstet Gynecol Neonatal Nurs 2009;38:567-76.

5. Bilert H. Tokophobia - a multidisciplinary problem. Ginekol Pol 2007;78:80-11.

6. Şahin N, Hüsniye D, Dişsiz M. Gebelerin doğuma ilişkin korkuları ve etkileyen faktörler. Zeynep Kamil Tıp Bülteni 2009;40:57-62.

7. Serçekuş P. Nullipar kadınlarda normal spontan doğuma ilişkin korkular ve nedenlerinin incelenmesi. Yayımlanmamış yükseklisans tezi, DEÜ Sağlık Bilimleri Enstitüsü, İzmir; 2005.

8. Ryding E, Wijma B, Wijma K, Rydhström H. Fear of childbirth during pregnancy may increase the risk of emergency cesarean section. Acta Obstet Gynecol Scand 1998;77:542-7.

9. Glover V, O'connor TG. Effects of antenatal stress and anxiety: implications for development and psychiatry. $\mathrm{Br} \mathrm{J}$ Psychiatry 2002;180:389-91.

10. Spielberger CD. State-Trait anxiety inventory. In: The Corsini encyclopedia of psychology. Hoboken. NJ: John Wiley \& Sons; 2010. 
11. Barnes LL, Harp D, Jung WS. Reliability generalization of scores on the Spielberger state-trait anxiety inventory. Educ Psychol Meas 2002;62:603-18.

12. Dobson KS. An analysis of anxiety and depression scales. J Pers Assess 1985;49:522-7.

13. Le Compte A, Öner N. Durumluk-sürekli kayg1 envanterinin Türk toplumunda geçerliliğ̣i. İstanbul: Boğaziçi Üniversitesi Basımevi; 1983.

14. Köroğlu E. Kaygılarımız, korkularımız. Anakara: HYB Yayincilık; 2006.

15. Uçar T, Gölbaşı Z. Nedenleri ve sonuçlarıyla doğum korkusu. İnönü Üniversitesi Sağlık Bilimleri Dergisi 2015;4:54-8.

16. Bilgin S, B1ldırcın FD, Alper T, Tosun M, Çetinkaya MB, Çelik H, et al. The effect of screening tests to maternal anxiety levels on pregnant women. Türk Jinekoloji ve Obstetrik Derneği Dergisi (TJOD Derg) 2010;7:206-11.

17. Dönmez S, Dağ H, Kazandı M. Amniyosentez öncesi gebelerde anksiyete ve depresyon risk düzeylerinin belirlenmesi. Acıbadem Üniversitesi Sağlık Bilimleri Dergisi 2012;3:25561.

18. Kıncı MF, Yeşilçınar I, Acavut G, Karaşahin KE. The opinions and thoughts of women who underwent hysterosalpingography for the first time: Letter to the editor. J Turk Ger Gynecol Assoc 2018;19:169.

19. Yesilcinar I, Yavan T, Karasahin KE, Yenen MC. The identification of the relationship between the perceived social support, fatigue levels and maternal attachment during the postpartum period. J Matern Fetal Neonatal Med 2017;30: 1213-20.

20. Kjærgaard H, Wijma K, Dykes AK, Alehagen S. Fear of childbirth in obstetrically low? risk nulliparous women in Sweden and Denmark. Journal of Reproductive and Infant Psychology 2008;26:340-50.
21. Spice K, Jones SL, Hadjistavropoulos HD, Kowalyk K, Stewart SH. Prenatal fear of childbirth and anxiety sensitivity. J Psychosom Obstet Gynaecol 2009;30:168-74.

22. Bayrampour H, Heaman M, Duncan KA, Tough S. Advanced maternal age and risk perception: a qualitative study. BMC Pregnancy Childbirth 2012;12:100.

23. Bardone AM, Moffitt TE, Caspi A, Dickson N, Stanton WR, Silva PA. Adult physical health outcomes of adolescent girls with conduct disorder, depression, and anxiety. J Am Acad Child Adolesc Psychiatry 1998;37:594-601.

24. Arslan B, Arslan A, Kara S, Öngel K, Mungan MT. Risk factors for pregnancy anxiety and depression: assessment in 452 cases. The Journal of Tepecik Education and Research Hospital 2011;21:79-84.

25. Hacettepe Üniversitesi Nüfus Etütleri Enstitüsü (HÜNE). 2013 Türkiye Nüfus ve Sağlık Araştırması (TNSA). Ankara: Hacettepe Üniversitesi Nüfus Etütleri Enstitüsü, TC. Kalkınma Bakanlığı ve TÜBİTAK; 2014.

26. Alehagen S, Wijma K, Wijma B. Fear during labor. Acta Obstet Gynecol Scand 2001;80:315-20.

27. Wiklund I, Edman G, Ryding EL, Andolf E. Expectation and experiences of childbirth in primiparae with caesarean section. BJOG 2008;115:324-31.

28. Betran AP, Torloni MR, Zhang JJ, Gülmezoglu A; WHO Working Group on Caesarean Section. WHO statement on caesarean section rates. BJOG 2016;123:667-70.

29. Ulubay M, Öztürk M, Fidan U, Keskin U, Firatlıgil FB, Kınc1 MF, et al. Skin incision lengths in caesarean section. Çukurova Medical Journal 2016;41:82-6.

30. Burns LR, Geller SE, Wholey DR. The effect of physician factors on the cesarean section decision. Med Care 1995;33: $365-82$. 